\title{
A Redescriptive History of Humanism and Hermeneutics in African Philosophy
}

\author{
Oladapo Jimoh Balogun \\ Department of Philosophy, Lagos State University, Ojo, Nigeria \\ Email: balothinktank@yahoo.co.uk
}

Received September 20 $0^{\text {th }}$, 2012; revised October $20^{\text {th }}$, 2012; accepted November $5^{\text {th }}$, 2012

\begin{abstract}
The aim of this paper is to contribute to the on-going debate about self-redescription in the history of African philosophy using the method and theory of redescription. This method and theory of redescription has become the deep concern of not only Western philosophers but of many African philosophers which is markedly present in their agitated pursuits of wisdom. This self-redescription is always resiliently presented in the works of Kwasi Wiredu, Kwame Appiah, Gyekye Kwame, Olusegun Oladipo, Wole Soyinka, Sophie Oluwole, Jim Unah, Martin Heidegger and Maduabuchi Duko;r who is the most recent emergence of the problem of theory and method in African philosophy. So, the general purpose of this paper is to enact the intellectual concern of this self-redescription in the history of African philosophy while the specific purpose is to determine the adequacy of humanism and hermeneutics as concepts covering the self-image of African philosophy. This paper will further show the incoherence and incongruence of humanism and hermeneutics with the concrete self-image of African philosophy by redescribing them in the mould of emerging concepts such as the humanness of Orisa intellectual culture, in particular; and orunmineutics as a general philosophical theory.
\end{abstract}

Keywords: Redescriptive History of Philosophy; Humanism; Hermeneutics; Humanness of Orisa Intellectual Culture; Orunmineutics

\section{Introduction}

This paper used the redescriptive theory of Charles Taylor to investigate conceptual history of African philosophy. This is being done with a view to reformulate three versions of humanism discussed in this paper with the concept of 'humanness', using the redescriptive consciousness of some African intellectuals and philosophers, in view of the problematic of the continuity and discontinuity between ancient African philosophy and contemporary African philosophy.

In this paper, we propose to suggest some other theoretical perspectives that can surcharge humanism and hermeneutics in African intellectual culture. This has been done by our re-redescription of humanism as the "humanness" of orisa intellectual culture; and orunmineutics as a redescriptive replacement for hermeneutics in the history of African philosophy.

\section{The Idea of Redescription in the History of Philosophy}

The history of philosophy has its own set of assumptions which grounds its disciplinary matrixes. Charles Taylor's theory of redescription is one amongst many of them. Instances of such set of assumptions and disciplinary matrixes abound in (Ogumodede, Francis, 2004; Rorty Richard, Schneewind, \& Skinner Quentin, 1984).

Creative redescription as propounded by Charles Taylor is a disciplined set of theoretical applications to historical problem in philosophy. Accordingly, for the aims and objectives of this essay to be accomplished, it is taken that the essence of the history of philosophy is "creative redescription" and that it would be difficult to be an accomplished philosopher if this is not taken as a serious methodological consideration.

What is creative redescription? Creative redescription manifests in a situation where the received idea about a people's philosophy and their set of practices is questioned and alternative descriptions are offered. To recreate, one has to begin with the enunciation of a self-image; such enunciation, it is claimed, take place at the level of ideas and invariably gives vitality to the concrete self-creative process of human beings everywhere. Without the interchange between redescriptive history and creativity in philosophy, the compass of human self-creation would be broken in the forest of existence.

Furthermore, Taylor concludes that it remains impossible to do any creative redescription without going back to the origins; without a genetic account of our origins which forces us to recognize the problem of conceptual continuities and discontinuities at the level of its intellectual dimensions. It is in the sense of this redescriptive concept of the history of philosophy that Charles Taylor argues that,

Philosophy is an activity which essentially involves, among other things, the redescription of what we are doing, thinking, believing, assuming, in such a way that we bring our reasons to light more perspicuously, or else make the alternatives more apparent, or in some way or the other are better enabled to take a justified stand to our action, thought, belief, assumption. Philosophy involves a great deal of articulation of what is initially inarticulated (Taylor, 1984: p. 18).

On this reinterpretation of Taylor's critique of the role played by W. V. O Qiune and Richard Rorty in the contemporary 
shaping of the history of philosophy as a struggle between the pro-epistemological model of the history of philosophy and its projection of the other as "unintelligible” supported by Qiune on the one hand; and the anti-epistemological model, which claims that no epistemological model has the overall epistemic understanding to be a judge over any other model of knowledge; as supported by Richard Rorty's pragmatism.

This position makes the critical problem of the unintelligibility of the "other" in the history of philosophy, possible. It is this opinionated dichotomy between pro-epistemology and antiepistemology, which grounds the point of view to be explored in this essay. From this point of view, it is clear that Taylor's creative redescription in the history of philosophy can be considered as a viable alternative Theory in the history of philosophy. It is pertinent therefore, that the requirements for this redescriptive history include the recovery of previous enunciations that have been cast off, the non-celebration of uniqueness, and the inter-cultural intelligibility of the other.

So, the Egyptian atum, the Akhenaton Aten, Anaximander's to aperion, Moses' I am that I am, Cartesian I think therefore I $a m$, the Einsteinium relativity $\left(\mathrm{e}=\mathrm{mc}^{2}\right.$ ), Oyibo's gagut ( $g i j, j=$ 0 ), Senghor's negritude, Soyinka's cosmic totality, Nkrumah's consiencism, Nyerere's Ujaama, Ben Okri's abiku, Dukor's theistic humanism, Buddha's fourfold theory of human emancipation from suffering, Schopenhauer's concept of will as suffering and compassion, the elephant dung motifs in Chris Ofilli's painting and Sophie Oluwole's Africanness of a philosophy; are exemplars of creative redescriptions in human intellectual history.

Nonetheless, these concepts above are presented as redescriptive alternatives in the history of philosophy. None of them offers any epistemic Archimedean point from which we can say that one description is more appropriate or adequate than another. In other words, our conceptual descriptions are contingent upon one another. This posit does not deny that some selfdescriptions are more influential than others, it claims, however, that the influence of one self-description over another is due to the power relations available at the time it makes its appearance and not because of its epistemic superiority over others. An example will suffice; the Hegelian self-description of Africa as a "dark continent" has been rebutted but this does not imply that it has stopped being influential as a concept in the history of philosophy. The criterion of truth does not imply here; since in the case of the history of philosophy, truth can be sought from any sources of knowledge and relevance can be sought from what is interesting and significant;

The relationship of thought to truth in the ambiguities of infinite movement has never been a simple, let alone constant, matter. That is why it is pointless to rely on such a relationship to define philosophy (Deleuze, Gilles, \& Guattarri Felix, 1994: p. 54).

If this is the case then, that there is no strict rule between thought and truth, what role has humanism and hermeneutics played in the redescriptive history of African philosophy?

\section{The Nature of Humanism}

Humanism is variously defined and the interpretations of these definitions are diverse. In its most general sense, however, humanism concerns that which centers on human interests and value within the universe. Additionally, humanism is the name given to the intellectual, literary and scientific movements of the fourteenth century to the sixteenth century, a movement which aimed at basing every branch of learning on the literature and culture of classical antiquity. The father of this type of humanism is Petrarch; the famous Florentine humanist (Ericson, 1980: p. 1).

Nonetheless, humanism has various other meanings, which would be impossible to exhaust here. Some views of humanism will be presented, which will be germane to the purpose of this paper. This is so because despite its generalized conceptions the word humanism has some distinct meanings; none of them, we can claim to be illegitimate. The classification of humanism that follows is Frederick Edword's answer to the question, what is humanism? (Edwords Frederick, 1989: pp. 1-12).

- Literary Humanism: The study of the humanities-literature, history, philosophy etc. In other words, the professors and students of history, philosophy and literature are humanists, just as the professors of physics, biology, chemistry are naturalists; what about the social scientists? They are neither humanists nor naturalist.

- Renaissance Humanism: This is the spirit of learning that developed at the end of the Middle Ages with the revival of classical letters and a renewed confidence in the ability of human beings to determine for themselves truth and falsehood.

- Cultural Humanism: This is the rational and empirical tradition that originated largely in Ancient Greece and Rome. It evolved throughout European history, and now constitutes a basic part of the western approach to science, political theory, ethics and law. The exemplar of this is hermeneutics: which began as a myth deriving its ontological significance as a god with social relevance. This is the point where hermeneutics as a social theory becomes interesting.

- Philosophical Humanism: Is any outlook or way of life centered on human needs and interests.

- Christian Humanism: Is defined as philosophy which advocates the self-fulfillment of human beings within the framework of Christian principles.

- Modern Humanism: This is also called Naturalistic Humanism Scientific Humanism, Ethical Humanism and Democratic Humanism. These are all concepts of humanism, which rejects supernaturalism relying primarily upon reason and science, democracy and human compassion. This sort of humanism has a dual origin, which is both secular and religious.

- Secular Humanism: This kind of humanism grows out of 18th century enlightenment rationalism and 19th century free-thought.

The real problem about these definitions is that humanists themselves do not agree on what humanism is. This is understandable since it is impossible for individuals not to exhibit the mental habits which influence their intellectual, moral, political, and religious judgments.

Even though, humanism is a concept which points to a set of ideas about human beings, the safest assumption one can make about the question, what is humanism? Is that scholar of humanism accepts humanism as a nebulous concept (Olorunleke Ojo, 2010). It is this nebulosity that makes humanism a concept that can be latched onto by any writer, researcher, author, enthusiast, who seeks to connect his thinking with the well being of humanity, even though, in the rudiment of their actions 
hardly is there the last vestiges of humanistic ethos. Yet, no matter what Archimedean point of view any enthusiast of humanism possesses; this point of view is imbued with a human gaze and perspective. Thus, the implication of most theism in philosophy is human authoritarianism, which marks the disaster of most philosophies that connect themselves with religions.

As a meta-theoretical concept, humanism has been used as the substratum of disciplines, methods, theories and ideologies. The interdisciplinary nature of humanism underpins its connection with religion, science, literature, ethics; science and many other ontological problems with which philosophy is involved.

In addition, humanism underlines basic issues in human knowledge and understanding in African philosophy. This is accentuated by Godwin Azenabor (Azenabor, 2010) assertion that African humanism is an adaptation of humanism to the concrete situation of the African. Yet, as a contested concept in philosophy, it is difficult to use humanism as the single selfimage of African philosophy.

In addition to this, as a human friendly concept it is easy to label the critiques of humanism as anti-human since they do not get caught up in the frenzy of humanism. As an honorific term, its influence cannot be ignored since its rejection is tantamount to the rejection of human values. But if the rejection of humanism is not the rejection of human values then what is humanism?

Humanism as an ideological construct has been linked with Marxism. In fact, this is underlined by Jean Paul Sartre's merger of existentialism with humanism. The safest way to characterize Sartre existentialist humanism is that to say that it is humanism without God; contra Heidegger, it is humanism without Being. Sartre claims that there is no God, or Being against which the actions of Human beings can be measured. Distinguishing between Christian existentialists such as Karl Jaspers and Gabriel Marcel on the one hand, [who claim that there is human nature as created by God], and Heidegger and himself, on the other hand [who claim that there is no human nature], Sartre enjoins us to accept the common fact that existence comes before essence. Humanism in this sense means that human beings are responsible for their actions. It is in being responsible for our actions as human beings, who cannot be measured by God since the freedom of man negates his existence, that humanism gets connected with the existential crises of choice and responsibility which invariably results in the uncertainty of values. Accordingly, the meaning of humanism has to do with commitment to the existential humanity of man and not to the essence of man; for the existentialist core of humanism is

The absolute character of the free commitment, by which every man realizes himself in realizing a type of humanity a commitment always understandable, to no matter whom, in no matter what epoch and its bearing upon the relativity of the cultural pattern which may result from the absolute commitment (Sartre, 1956: p. 351).

A reaction to this from the perspective of Martin Heidegger would show that humanism presupposes human knowledge based upon the relation between Being and its activity of thinking and not the purported absolute freedom of Sartre. On Martin Heidegger's account, the defense and appropriation of humanism is unnecessary since it is a rush to satisfy the de- mand of the market;

You ask: Comment redonner un sens au mot "Humanisme? [How can we restore meaning to the word "humanism"] This question proceeds from your intention to retain the word "humanism." I wonder if that is necessary. Or is the damage caused by all such terms still not sufficiently obvious? True, "isms" have for a long time now been suspect. But the market of public opinion continually demands new ones. We are always prepared to supply the demand. Even such names as "logic," "ethics” and "physics" begin to flourish only when original thinking comes to an end (Heidegger, 1978: p. 195).

Whatever a human being knows cannot go beyond the relationship between thinking and Being, a relationship which confers on humanity, its humanness. Understanding is a fusion of emotive and rational knowledge. It is this that forms the basis of human knowledge and its interpretation. Being thrown according to Martin Heidegger, is a human possession, therefore, in reiteration, there is no knowledge other than what we are capable of as humans. Accordingly humanism for Heidegger is meditating and caring which distinguishes being human from being inhuman. To be inhuman is to be outside one's essence.

Heidegger's takes contrary stand against Jean Paul Sartre's equalization of existentialism with humanism, claiming that humanism underestimate man's unique position in the light of being. Furthermore, it is precisely because humanism underestimates the "standing out of human life to the truth of being" that he rejects humanism (Heidegger, 1946: p. 191).

\section{The Relationship between Humanism and Self-Redescriptions in African Philosophy}

The use of humanism has become commonplace especially in the redescriptive history of African philosophy. It is asserted by Azenabor that African humanism has been a recurrent theme in African philosophy (Azenabor, 2010: p. 115).

However, it should be noted that when it is used, humanism is not placed on the pedestal of critique, which could question the historical and intellectual repositioning of its emergence in African philosophy and whether it sufficiently describes or covers the philosophical experiences of Africans. In most cases, what we witness is the strange imposition of foreign concepts on indigenous epistemic orientations. The upshot of this, is that humanism has become an increasingly redundant concept to describe or re-describe the intimate human experiences in African philosophy. Humanism is an over-generalized description of African humanity in African philosophy. Azenabor declares further that;

African humanism, as an African thought system, stresses relationships among people in society that is, interdependence, rather than bold descriptions of individual events in human experience or individualism (Azenabor, 2010: p. 115).

How? Humanists in African philosophy present their versions, as if it is what everyday Africans conceive, project and must accept. But on the views of Jim Unah's that human life is always a transcendence from what is to what is not and its Heideggerian import that human life is an ecstatical possibility, then a sustained redescription should open the history of Afri- 
can philosophy to other alternatives of humanistic ethos.

Unah (2002: p. 127), furthermore, it is difficult to ignore the admonition of Kwame Appiah, that the idea of a single selfimage of the African world is a myth (Appiah, 1992: p. 83). This critique can be located in the pursuit of wisdom by three prominent African philosophers, who are Kwasi Wiredu, Sophie Oluwole and Maduabuichi Dukor on humanism.

First, it must be stressed that these individual philosophers represent bold self-redescriptive efforts to relocate humanism as an open ended construct of ideas in African philosophy, which marks their own ingenuity and creative concern with concepts and themes of African philosophy.

In the light of this, Kwasi Wiredu conceptualizes the moral foundation of African philosophy in the suggestion that a contemporary Akan is not a supernaturalist but a humanist (Wiredu, 1995: p. 3). Although, Wiredu does not expressly claim that he is pursuing the course of humanism, in this essay, however, in Olusegun Oladipo's introduction to the essays in honour of Wiredu, he (the most influential philosopher on Wiredu) presents four key points of Wiredu's philosophy with the submission that Wiredu makes humanism a core of his philosophy. Olusegun Oladipo says that Wiredu makes:

A conscious attempt to develop an African tradition of humanism in which knowledge and values are nothing unless they serve the purpose of promoting human wellbeing (Oladipo, 2002: p. 14).

In his contribution to humanism in African philosophy, Wiredu argues that Akan morality is oriented towards humanistic ethos and not supernaturalism (Ibid, 1995: p. 37). Here Kwasi Wiredu is engaging in a self-redescription of Akan morality, which in itself is worthwhile but his claim about Akan humanism is very problematic. It gives the untoward implication that every Akan would subscribe to the conclusion that Akan Morality is not oriented towards supernaturalism.

This redundancy of humanism as a concept in human engagement with its well-being is thematically enforced in Martin Heidegger's Letter on humanism, in which he argues that humanism as a concept covers up the "humanity" of human beings. Accordingly humanism functions as a concealing outfit for the homelessness of "human life" in a world that should have been his home. Thus, the question "How can some sense be restored to the word 'humanism'?" means that grace has been removed from the word humanism which is used, ultimately, to describe the concern of man with human life. Since the word humanism describes the anxiety of man with himself cutting of the umbilical cord which connects human beings with supernatural forces, would Wiredu argue that Akans do not believe in ancestral guidance, if not worship? This selfredescription by Kwasi Wiredu of Akan Morality as humanism is a signpost of misdirection, which does not express the collective experience of Akan foundation of morality as the essay purports to show.

Another philosopher who has engaged in self-redescriptive effort in African philosophy is Sophie Oluwole and whose concept of humanism is embedded in her idea Africanness of philosophy (Azenabor, 2010: pp. 110-133). Her cautious approach towards re-describing the concern of African philosophy as the "pursuit of humanism" is noteworthy. The pedagogic import of these has been drawn out by Godwin Azenabor in his essay on Oluwole's “Africanness of a philosophy”. Even though she attempts to show that the Humanism she favours has once had an existence amongst the Greeks; it is a humanism which is still imbued with the interpretation of the renaissance literary mission.

However the content of her frame of mind on humanism promotes and deepens the "humanness" of African philosophy rather than the Humanism of African philosophy. But for the use of the problematic conceptual label, "humanism"; Oluwole's self-redescription on African philosophy would have been distinguished more than the notion of the collective. Our finding here, is that Oluwole confuses her undertaking with the task of Petrarch the father of humanism. Petrarch devoted his life to the recovery, copying, and editing of Latin manuscripts. Yet, their tasks are different. Since Oluwole concerns herself with the location of philosophical concepts in Ifa corpus in both its oral offering and literary readings. Whatever the conception of her philosophical mission, it is no longer "humanism". Her concern with the recovery, translation and interpretation of oral offerings of Ifa Corpus and doubt concerning what may have been ascribed to Orunmila goes to show that she intends to exhibit the primordiality of the African philosophical experience. She is concerned with the "grace of humanness" offered by the indigenous knowledge of African traditional society.

The third and most recent germane description of humanism in African philosophy is Maduabuichi Dukor's theistic humanism.

Dukor presents a conglomerate of ideas; (western and African) using theistic humanism as its umbrella concept and hermeneutics as its theoretical framework. Our interpretation of Dukor will be based on these dual perspectives.

Dukor claims that the definition of African philosophy is theistic humanism. Theistic humanism is an acknowledgment of the theistic and humanistic undertone of African philosophy and its scientific nature. Furthermore, Dukor claims that theistic humanism could be the basis and justification of the third world countries struggle for justice in a lopsided world order. Since theistic humanism is a concept or doctrine which designates African inclusive idea of God, man, and universe; theism and humanism are both categories of humanism. In this way, the legitimacy of African philosophy becomes enunciated as the claim that,

African philosophy so defined renders the religious, myths and symbols as rational and coherent system as well as constituting a material or a fabric for philosophical enterprises, much so there is also evidence of myths and symbols in the history of western philosophy (Dukor, 2010: p. ix).

Apart from theistic humanism; Dukor claims that an authentic African philosophy must proceed from spirituality since, for the African "man is the measure of all things while essence precedes existence”, therefore, African life is subject to God. Furthermore, he defines theistic humanism as the theory and view that the literary endeavours, worldview, or cosmology, ontology, aesthetics, ethics and politics of Africans are spiritual. Succinctly put, theistic humanism is an afro-ontological conceptualization of being human in the midst of all forms of humanism and its theistic formulation.

However, it must be noted that Dukor ignores the caution of Martin Heidegger that philosophers should be careful the way they use humanism as concept of utility rather than that of ac- 
complishment between thinking and Being. Seen through this light, Jim Unah's discourse on the otology of man where we are again warned against the ideological representation of the Being of man and shown the significance of his mental power is pertinent. According to Jim Unah human reality is a summary or an epitome or a small version of the world. He further opines that:

The way the world, Reality or Being manifests in contradictory terms so too is man himself a bundle of puzzles and contradictions. Thus, if one wants to understand how the world, Reality, Being, truly is one should first of all understand the porousness and contradictions inherent in human reality. Human being is a microcosm of a macrocosm (Unah, 2002: p. 145).

Unah's and Heidegger's reliance on the mental power of man and its understanding of human life call into question Maduabuichi's Dukor theistic humanism and points us to the intellectual direction of human life through thinking and not necessarily spirituality or theism.

The presumption of Dukor is that African philosophy cannot but be both humanist and theistic but the problem with this, is that not all Africans are theists. In fact, the current presentation of theistic humanism is an oversight of Appiah that the idea of single self-image Africa is a myth. Before Appiah, Bodunrin has appealed to the individualist intellectuality of Africans; thus it goes without saying that theistic humanism is an over-generalization of the African conception of humanism. If we pair Oluwole intellectual humanism with Dukor's theistic humanism, we simply come to the interpretation that the average conception of humanism is intellectual rather than theistic. Dukor's theistic humanism gives the impression that humanism in African philosophy is monolithic and not multiple.

Leaving the problem generated by theistic humanism alone we come to the problem of Hermeneutics which is another influential theory in philosophy especially African philosophy. The influence of hermeneutics in African philosophy forces one to ask whether we as Africans are bereft of ancient and modern intellectual ancestors that almost all foreign concepts created and invented is appropriated to the redescription of theories in African philosophy. Just has Martin Heidegger applies the redundancy of theory concept in his treatment of humanism so we are going to do. It is redundant because it makes no sense to be continuously caught in the web of intellectual ancestors who are no longer relevant to the intellectual need of Africans and their cultural development.

The interpretation above has shown that the relation that exists between Humanism and self-redescription in African philosophy is the failure to engage in conceptual formation which would properly describe or cover the spectrum of African experience in philosophy. The three self-redescriptions in African philosophy presented above shows that "Humanism" is inadequate when describing the African experience in philosophy.

\section{The Nature of Hermeneutics}

Hermeneutics is both a theory and method which has grown out of the social role and abstract conception of the Greek god; Hermes. Hermes was the messenger of the gods in both Iliad and Odyssey. In other to carry out this function, Hermes had to bridge an ontological gap between the thinking of the gods and human beings. Hermes possessed a mysterious helmet which could make him invisible and visible; magical wings on his sandals to carry him promptly over long distances and a magical wand that could put any one to sleep and wake up. Accordingly, he was regarded as the "god of gaps" of the margins, the boundaries, the limns of many things. Hermes was a liminal phenomenon (Palmer, 1999: p. 2).

Thus, the theory and method called hermeneutics holds within its formulation mythical and theological implications. Especially when considered as the theory underpinning the whole of Dukor's theistic humanism. The root of hermeneutics as a philosophical approach to inquiry is linked with Aristotle who narrowly defined hermeneutics in terms of the determination of the truth and falsity of assertions. However, Palmer claims further that the words hermeneuein, hermeneia and their cognates were widely used in ancient Greek to mean interpretation in several senses (Palmer, 1999: p. 2).

The first of such senses is the oral interpretation of Homer and other classic texts who were called Hermeneutic; the second of such senses is translation from one language into another and the hermeneutical process involved in this is the problem whether translation is free from interpretation and third, is the exegesis of texts; the hermeneutical process involved in this is the interpretation which involves the bringing out of meaning, especially hidden meaning in texts. Hermeneutics is the explicating of dreams, oracles, and other difficult texts, including legal, religious and literary texts (Palmer, 1999: p. 2).

As an art of interpretation, Hermeneutics underpins the application of human understanding to various disciplinary attitude such as theology, law and the scripture and even science. It has been used as a general theory of human understanding by Friedrich Schleiermacher, Wilhelm Dilthey, Martin Heidegger, Hans-Georg Gadamer, Paul Ricoeur and Jacques Derrida. Each of these intellectuals has used hermeneutics in different ways that sustained the critique of modernity and its consequences on the problem of existence. Although Hermeneutics does not reduce critical thinking into relativism; it however, accepts and recognizes the historicity of human understanding. It is the practice of historical retrieval and the re-construction of the historical context of scientific and literary works (http://groups.chass.utoronto.ca/iih/AboutHermeneutics.htm, 2013).

Furthermore, Hermeneutics guide intercultural relation, since it is formulated within the ontological and linguistic gap that operates amongst cultures. Its most important contribution is that it gives the opportunity to understand better that which is at stake in intercultural interactions. It is this opportunity that accentuates the Hermeneutician critique of radical relativist who claims that meaning cannot be trans-lingual.

Essentially, dialogical understanding is the strength of Hermeneutics, as it constantly calls for the openness and solidarity that is needed in inter-disciplinary, inter-linguistic, inter-religious and international collaboration (Ibid, 2013).

\section{A Rediscriptive History of Hermeneutics in African Philosophy}

From the above enumeration of Hermeneutics, it is clear that Hermeneutics is a Euro-centric intellectual source that relies on the Greek God of Liminality: Hermes. This god and his many attributes have been appropriated by many philosophers across cultures including many European philosophers, Asian philosophers, African philosophers, American philosophers as 
alternatives of theoretical experiences in philosophy. These alternative theoretical experiences, it may be argued, have been engaged in, in other to subvert science and positivism as a disciplinary authority in epistemology and the history of knowledge.

As an inter-cultural theoretical and methodological concept, Hermeneutics has become handy for some influential African philosophers in their bid to re-describe African philosophy away from its ethnographic, analytic and sagacious influences; while maintaining its professional integrity. Such African philosophers are; Serequeberham, Tseney (1994), Okolo, Okonda (1991), Owolabi, Kola (2001), Obi, Oguejiofor (2009) and Dukor, Maduabuchi (2010).

An application of redescriptive history of philosophy to these philosophers' use of Hermeneutics would show that while they have achieved a lot theoretically and methodologically for African philosophy, there is no doubt they failed to connect with their primordial intellectual culture. This historico-ontological gap in the theoretical and methodological history of African philosophy calls for an interpretation that brings into focus the relevance of ancient African philosophy and its contribution to contemporary social theory.

In the explication of the failure of contemporary African philosophic thought in terms of its thematic relation to the discourse of the African liberation struggle Tseney, Serequeberhan introduced Hermeneutics as the theory which closes the ontological gap that exist between ethnophilosophy and its professional critics (Serequeberham, 1994: p. 118). As a liberating theory, Serequeberham's hermeneutics poses the problem of the concrete historicity of postcolonial African philosophic thought. He argues further that;

Through all of the above, this study has presented African philosophy as a critical hermeneutics of the African situation. In its specific arguments and formulations, this study has been grounded in the concrete awareness that philosophy in general and African philosophy in particular is, above all else and necessarily, a hermeneutical thinking through of its own historicalness (Serequeberhan, 1994: p. 118).

Let us agree with Serequeberhan that there is the need for theoretical intervention in the discourse concerning the selfimage of African philosophy, but can the challenge of "decolonizing the mind" be met with Hermeneutics: another colonial theoretical formulation?

If the aim of Serequeberhan is to defend the emancipating need of the African mode of life and its indigenous philosophies in African languages, must our cultural motifs neglect our origins; tradition and destiny?

Okolo, Okonda (1991) while not explicitly giving vent to the not-too-necessary role of hermeneutics in African philosophy; keeps vacillating between the cultural gap and social theories that exists between tradition and destiny in contemporary African philosophy asks;

And what about us, what is our vision of the world, and what is our idea of destiny that directs our readings and our retakes? Can we align ourselves with the vision of the world, with the idea of destiny, secreted by European hermeneutics without implicitly negating our own tradition and our own history? Can we simply reverse this vision of the world, this idea of destiny, and brandish our spiritual superiority in front of a technicized (technicisèè) and materialistic Europe without falling back into a twisted Hegelianism? (Okonda, 1991).

Within these questions, Okolo concludes that we have to proceed from the hermeneutical approach in other to emancipate ourselves intellectually from European dominance; but do we need the theoretical tool of a European God? Are there no gods in Africa that can be critically scrutinized and elevated to a more fulfilling intellectual pedestal such as the Greeks did with Hermes and European intellectuals with hermeneutics? These redescriptive questions affect the researches that have buried the authenticity of contemporary African philosophy within the theoretical circle of hermeneutics. Such researches using Hermeneutics as both a theoretical and methodological approaches fall under the same critique under which Tseney Serequeberhan has been subjected.

So, Owolabi's Hermeneutic-Narrative approach in African philosophy; Oguejiofor Obi's reinterpretation of Negritude as hermeneutics, Maduabuchi Dukor's Hermeneutical method in theistic humanism where the essence of man is critically elevated over his existential projections, and Theophilus Okere (1983) Historico-Hermeneutical investigations of the conditions of the possibility of African philosophy, all embark on the same theoretical route: the imposition of Greek cultural identity on African philosophy. But, how do we respond to these problems from the perspective of primordial African concern with its humanity? These question raised above will be the focus of our attention immediately.

\section{Reformulating the Problem of Theory and Method in African Philosophy: Orisa Intellectual Culture}

From the above, it would be grasped that we need to pay attention to creation and formation of concepts in African philosophy. A crucial problem that we need to tackle now is the problem of alternative theories to humanism and hermeneutics in the history of African Philosophy. There are strong arguments in favour of the position that contemporary African philosophy is discontinuous with its ancient origins. It can no longer be denied, however, that most contemporary African philosophers have turned their attention to concepts and theories formulated by ancient thinkers and have explored the relevance of these concepts to contemporary problems. In line with this observation, we present three major contemporary African philosophers who have explored the orisa intellectual culture to establish this continuity. These three philosophers have the same cultural background; Yoruba cultural background, but we in no way claim here that this cultural background is the only cultural background through which the redescriptive of African philosophy could be enacted; it is just one among many of such cultural background.

Sketches of the Orisa intellectual culture have appeared in the works of Wole Soyinka who has explored the humanness of the orisas in his major works. Some contemporary African philosophers have appropriated the pattern of openness, solidarity and dialogue with which this intellectual culture is imbued. Such philosophers that have appropriated this intellectual culture are Unah (2006: pp. 16-19) in his attempt to grapple with problem of "Nothing” and Appiah (1992: pp. 73-84) in his ontological interpretation the African situation in the philoso- 
phy of culture.

It must be noted that the concept orisa is used as a parallel to the concept philosopher; the lover of wisdom. In a dialogue, Ulli Beier and Wole Soyinka characteristically explore the humanity of the orisa beyond the popular conception of their divinity. The both came to conclusion that the Orisa were human beings who like the ancient Greek philosophers made discoveries of elements and the primal stuffs of reality;

I can find parallels to Yoruba concepts here on several levels. The artist as the "creature of dissatisfaction with immediate reality" is really very reminiscent of the orisha, who starts life as a human being-a king or a warrior- but because of his dissatisfaction with the immediate reality "leads a raid into that other world." (Soyinka \& Beier, 1997: p. 10).

The human being dissatisfied with immediate reality returns as the human being whose new knowledge of phenomena gives the privilege of the relation between Thinking and Being. The orisa comes back to the real world with ideas that have become useful or destructive to mankind; depending on his time of appearance. Thus, the orisas are human beings who confronted by the need to find solutions to problems; lead an intellectual raid into other world; the world of ideas and come back with an answer. The orisa start out as human being and end being deified. Just as Thales found out that water is the ultimate primal stuff so did Osun discovered the importance of water to human life, Ogun discovered iron and was able to create pathways with it, Sango, parallel to Heraclitus, took fire to be his own primal stuff becoming the demiurge of electricity in modern Yoruba era.

Soyinka stresses further that the orisas are the custodian of wisdom. The humanness of the orisa is further demonstrated in their capacity for understanding and intuitive grasp of complexity of the infinite mind and a true sense of the infinite potential of the world. The humanness of the orisa is reflected in their purity, love, transparency of heart and so on (Soyinka, 1991: pp. 32-35).

The point being made here is that contemporary African philosophers have followed this trend and have sought both methodological and theoretical pathways in Ancient African philosophy. Oladipo Olusegun (2007: pp. 1-12) is a conspicuous example. As a contemporary African philosopher Oladipo complains about the situation wherein African philosophers have submitted their 'intellectual future' to others; appealing to Paul Hountondji, he argues that contemporary African philosophers confine themselves to the role of producers of intellectual raw materials; allowing metropolitan scholars to supply them with finished intellectual products, in terms of theories, while further data is generated in other to justify these theories about our societies and cultures. This redescriptive process of historical origins of the intellectual foundations of African philosophy is possible only when concepts, theories and methods are rediscovered and presented for the sake of human-well being. In his further analysis, he argues that Yoruba primordial divinities stand for certain core values which are in-negligible as cultural and philosophical theories. He shows that, Orunmila stands for knowledge and wisdom; including historical knowledge as a witness of destiny, Orisa-nla (Obatala) stand for creativity and forthrightness, while Ogun stands for power and courage. This posit is again accentuated by Oluwole, Sophie (1999) who continuously insist that African oral tradition holds within it, inter- esting and significant philosophical kernel with which contemporary African philosophers can re-describe their present methodological and theoretical situation. According to her, it is impossible to come into contact with authentic African philosophy without first engaging the oral traditions of ancient wisdoms. Oluwole's emphasis on Oral tradition brings into focus the problem of continuity and discontinuity in African philosophy and its connection with the emergence of the orisa intellectual culture which we have enumerated above.

The main thrust of the argument in this part of this is that parallel line can be drawn between ancient Greek philosophy and ancient African philosophy. It has also being argued that just as there is a continuity between ancient Greek Philosophy and contemporary Western philosophy so also there is continuity between ancient African philosophy and contemporary African philosophy.

It is important to note that the critique of Humanism does not necessarily involve the rejection of the humanistic values which connects human beings together. The rejection of humanism is not the rejection of the humanity of Africans but the rejection of the usage of a second-hand label as suggested by our tripartite contemporary orisas (Wole Soyinka, Olusegun Oladipo and Sophie Oluwole) to describe and explain the philosophic experiences of Africans.

Now to the question, what is the concept that can describe and explain the activities of these African philosophers? What we suggest is that Contemporary African philosophers should continue to work in the primordial region of African experiences which could usher them into the grace of the "Humanness" that makes up the African experience in its everyday occurrences.

So, the foundation of Akan morality is its "humanness" its concern with the well-being of the human beings that inhabit the cultural space of Akan morality. What Sophie Oluwole tries to discover is the "humanness" present in African philosophy through her romantic involvement with Orunmila; the creator of Ifa corpus, Olusegun Oladipo's tripartite conception of reality from the substance of Yoruba philosophy and Wole Soyinka's humanization of the orisas through his tripartite conception of the theory of literary culture.

\section{Conclusion}

The discussion above has taken us through different levels of self-description and re-redescription in African philosophy. It has been suggested that humanism and hermeneutics as a concept do not sufficiently describe the concern with African humanity in the philosophy of Kwasi Wiredu and Sophie Oluwole and Maduabuichi Dukor. It is therefore, suggested that what this philosophers are doing is not humanism, but the rediscovery of "humanness" in African cultural philosophy. This idiosyncratically expresses itself in theory of Orisa Intellectual culture, its method being Orunmeneutics.

What is orunmineutics? It is a redescriptive theory and method in African philosophy. Its initial obligation is to connect ancient African philosophies with its contemporary counterparts. It seeks the relevance of intercultural, interdisciplinary, interlinguistic, interreligious, and international dialogue, solidarity and openness. As a procedure of research; it is a metascientific and multicultural process through which the humanness of the human being gets explication and possibilities that are available within the ecstatic conception of time. As a limi- 


\section{O. J. BALOGUN}

nal theory and method takes over the cultural ontological gap in African philosophy; in which humanism and hermeneutics are receding. The nature of orunmineutics are numerous, but what should be noted is that the intellectual clarion call to rethink our methodologies and theories in contemporary African philosophy should not be neglected if African philosophy is to be regarded as veritable in the intellectual history of philosophy in general. Thus, the philosophers in this essay use orunmineutics as long as they are conscious of the present world tradition of pluralism, multiplicity and multiculturalism.

\section{REFERENCES}

Appiah, K. A. (1992). In my father's house: Africa in the philosophy of culture. Oxford: Oxford University Press.

Azenabor, G. (2010). Modern theories in African philosophy. Lagos: Byolah Publishers.

Bodunrin, P. O. (1981). The question of African philosophy. Philosophy, 56, 161-178.

Catholic Encyclopaedia (2003). Humanism, 7. URL (last checked 17 February 2013). www.newadvent.org

http://groups.chass.utoronto.ca/iih/AboutHermeneutica.html

David, R. B. (2003). Why UU humanism requires rejecting our humanity. URL (last checked 15 December 2012).

http://americanunitarian.org/humanity.htm

Deleuze, G., \& Felix, G. (1994). What is philosophy. London: Verso.

Dukor, M. (2010). Theistic Humanism of African philosophy: The great debate on substance and method of philosophy. Germany: Lap Lampart Academic Publishing Gmbh \& Co. KG.

Edwords, F. (2004). What is Humanism? URL (last checked 5 December 2012).

http://www.co.infidels.org/library/modern/fred_edwords/humanism.h tml

Ericsson, L. E. (1988). The humanist way. New York: Continuum Publishing Company.

Gloria, K. F. (1992). The humanistic tradition (Vol. 2). London: Brown and Benchmark.

Maduabuchi, D. (2010). Theistic humanism of African philosophy: The great debate on substance and method of philosophy. Germany: Lap Lampart Academic Publishing Gmbh \& Co. KG.

Martin, H. (1978). Letter on humanism in martin heidegger basic writings. London: Routledge and Kegan Paul.

Oguejiofor, J. O. (2009). Negritude as hermeneutics: A reinterpretation of Leopold Sedar Senghor's philosophy. American Catholic Philosophical Quarterly, 83, 79-84.

Ogunmodede, F. (2004). African philosophy down the ages: 10,000 BC to the Present. Ibadan: Hope Publications.
Okere, T. (1983). African philosophy: A historico-hermeneutical investigation of the conditions of its possibility. New York: University Press of America.

Okolo, O. (1991). Tradition and destiny: Horizons of an African philosophical hermeneutics. In Tsene Serequeberhan: African Philosophy the Essential Readings. New York: Paragon House.

Oladipo, O. (1996). Philosophy and the African experience: The contributions of Kwasi Wiredu. Ibadan: Hope Publications.

Oladipo, O. (2002). Third way in African philosophy. Essays in Honour of Kwasi Wiredu. Ibadan: Hope Publications.

Oladipo, O. (2007). The substance of Yoruba philosophy. Journal of Yoruba Studies Association of Nigeria, 4, 1-13.

Olorunleke, O. (2010). Marxist criticism and the humanist ethos in Nigeria. A Seminar Paper, Ojo: Lagos State University.

Oluwole, S. (1999a). Oral tradition. Lagos: Ark Publications.

Oluwole, S. (1999b). The Africanness of a philosophy. Lagos: Ark Publications.

Owolabi, K. (2001). The quest for method in African philosophy: A defense of the hermeneutic-Narrative approach. The Philosophical Forum, 32, 147-163.

Palmer, E. R. (1999). The relevance of Gadamer's philosophical hermeneutics to thirty six topics or fields of human activity. URL (last checked 5 December 2012).

http://www.Mac.edu/faculty/richardpalmer/relevance.html

Robinson, G. D. (1995). Paul Ricoeur and hermeneutics of suspicion: A brief overview and critique. Premise, 2, 12.

Rorty, R., Schneewind, J. B., \& Skinner, Q. (1998). Philosophy in history: Essays on the historiography of philosophy. Cambridge: Cambridge University Press.

Sartre, J. P. (1956). Existentialism is a humanism. Ontario: New American Library.

Serequeberhan, T. (1994). The hermeneutics of African philosophy: Horizon and discourse. New York: Routledge.

Steven, D. S. (1998). The history and philosophy of humanism. URL (last checked 12 December 2012) http://www.jen.com/humanism.html

Taylor, C. (1984). Philosophy and its history. In Rorty et al. Cambridge: Cambridge University Press.

Unah, J. (2005). On being: Discourse on the ontology of man. Lagos: Fadec Publishers.

Unah, J. (2006). Even nothing is something. Akoka: University of Lagos Press.

Wiredu, K. (1995). Conceptual decolonization in African philosophy: Four essays. Ibadan: Hope Publications.

Wole, S. (1991). The credo of being and nothingness. Ibadan: Spectrum Books Limited.

Wole, S. (1997). A conversation with Ulli Beier. Isokan Yoruba Magazine Summer, 3. URL (last checked 17 December 2012). http://www.yoruba.org/magazine/summer97/f 